\title{
Boosting service innovation: the role of consultancies
}

\author{
Manuela Pinto \\ manuelafdias@gmail.com | University of Porto - Faculty of Economics \\ Irina Saur-Amaral \\ isaur@ua.pt | Universidade de Aveiro (ISCA-UA \& GOVCOPP-UA), Campus Universitário de \\ Santiago, Aveiro - Portugal \\ Carlos Brito \\ cbrito@fep.up.pt | University of Porto - Faculty of Economics
}

\begin{abstract}
This paper seeks to make a particular contribution in what are the roles of consultancies as key innovation intermediaries in service industry. Intermediation literature mostly focuses on the analyzing the contribution of intermediaries in manufacturing context and in technological innovation. More recently, the importance of intermediaries in service context and non-technological innovation has been discussed. In line with the emergent literature, the research aims to shed more light on the perceived importance of consultancies as innovation intermediaries in service industry, from the point of view of service clients. Four in-depth case studies of service companies were developed, resulting on detailed descriptions of the phenomenon using constructs to order the data and relate to earlier literature. Key findings highlight changes in motivations for consultancy engagement, from an initial focus on knowledge (output) to a focus on methodology (process). A new function of intermediaries arises from this study, related with "evaluation of innovation outcomes". The study highlights the contribution of consultancies in preparing companies to innovate.
\end{abstract}

Keywords. Consultancies; Innovation Intermediaries; Service Companies; Motivations; Collaboration Process, Results.

Cite paper as: Pinto, M., Saur-Amaral, I., Brito, C., (2019). Boosting service innovation: the role of consultancies, Journal of Innovation Management, www.open-jim.org, 7(3), 41-68. 


\section{Introduction}

Innovating is complex, and partnerships with other players in the innovation system are critical to boost companies' innovation activities. Innovation intermediaries play a critical role in an innovation system, helping to reinforce the innovative capacity of companies, industries, regions and nations (Dalziel, 2010). They facilitate the access to external knowledge of other players in the innovation system, providing information, access and funding (Chesbrough, 2006).

There is a growing literature addressing the roles of innovation intermediaries in manufacturing industry, focused on technological facet of innovation. Yet, in service industry context, this topic is still under explored. Services are of paramount importance in world economies and there is growing literature investigating service innovation. Even though there is not a unique service innovation mode, service companies innovate somewhat differently from manufacturers, focusing on the soft side of innovation and on non-technological innovations (Castro et al, 2011; Tether, 2005). Furthermore, the studies of service innovation have the potential of highlighting features of innovation that have been largely ignored in manufacturing studies (Castro et al, 2011; Drejer, 2004), contributing to a synthesis approach.

To address the literature gap, Pinto et al (2016) proposed a conceptual tool for analyzing the role of intermediaries within service innovation, highlighting the importance of consultancies and universities as innovation intermediaries in service industry. To our best knowledge, this was the first framework describing the functions of intermediaries in services context, and it drew on an enlarged view of innovation (technological and non-technological). In a subsequent empirical study, Pinto et al (2017) confirmed the applicability of the framework within consultancies, using a case study approach to analyze the engagement between service companies and consultancies, from the point of view of the later ones.

Our study aims to contribute to the existing knowledge on the role and importance of innovation intermediaries, more specifically consultancies, in service industry innovation. Using a multiple case study design, and focusing on the perspective of service companies, the research intends to answer the following questions:

1) Why service companies engage consultancies (motivations \& expectations)?

2) How do consultancies support the innovation processes of service industry (types of projects, models of engagement, roles \& functions of consultancies)?

3) How do consultancies add value to the innovation process of service industry (main contributions; outputs; challenges)?

The paper is organized as follows. Section two includes a brief review of existing literature on innovation intermediaries, with a specific focus on consultancies, and on service innovation. Section three is dedicated to methodological issues. In the fourth section, findings are analyzed and discussed. Section five concludes and section six presents the study limitations and future research propositions. 


\section{Innovation Intermediaries}

\subsection{Importance and functions}

Innovation intermediaries are organizations or groups within organizations that work to enable innovation (Dalziel, 2010). As innovation becomes a more open process, intermediaries provide services in three critical areas: information, access to other players and funding (Chesbrough et al., 2006). They bridge the gap between internal and external know-how, reducing the time to market and the time to know-how, increasing the firm's efficiency in product development and the efficiency of its external service providers (Gassman et al., 2011). They connect different players in the innovation system in order to facilitate the outsourcing of innovation, by reducing the associated costs and by helping to overcome barriers to innovation technologies commercialization (Chu, 2013).

Innovation intermediaries provide many value-adding functions of innovation supporting links, in the areas of IP or technologies trade (Chu, 2013). Their functions may include: Foresight and diagnostics; Scanning and information processing; Knowledge processing and combination/recombination; Gate keeping and brokering; Testing and validation; Accreditation; Validation and regulation; Protecting the results; Commercialization; and Evaluation of outcomes (Howells, 2006).

Intermediaries can operate has a mediator, in simple or more complex triadic relationships, or they can supply services directly to their clients, without the interference of other parties (Klerkx and Leeuwis, 2009; Howells, 2006). Relationships between intermediaries and their clients tend to be longer, to allow reinforcing mutual knowledge and trust (Howells, 2006).

There is a growing number of studies on innovation intermediaries, with a pragmatic focus. The intermediaries' functions have been extensively analyzed, yet, the emphasis is on their contribution to the processes of technology acquisition and transfer, on manufacturing context. The literature mostly focuses on brokering role of intermediaries and they are understood as facilitators or mediators in the process of innovation diffusion across organizations and industries (Howells, 2006; Caiazza e Volpe, 2016; Lin et al, 2016; Battistella et al, 2016; Cantú et al. 2015).

A search on the database Current Contents Connect of Web of Science covering the late 20 years (from 1998 to 2017), under the topics "innovation intermediaries" and "service innovation", revealed that only 3 articles (from a total of 102 articles) were published on journals focusing on service innovation. Furthermore, these three articles address specifically the role of intermediaries as service providers, not analyzing their contribution to service industry innovation. Another search, combining the keywords "innovation intermediaries" and "non-technological innovation", did not exhibited results.

The intermediation literature bias towards technological innovations limits its application in service industry (Pinto et al, 2016). Service innovation comprehends a lot more than a change in the characteristics of the product itself (Den Hertog et al, 2010), and favors the introduction of organizational and marketing innovations. Besides technological capabilities, human and organizational capabilities are also central for delivering services (Den Hertog, 2010). The bro- 
kering function of intermediaries arguably loses significance in services since the introduction of non-technological innovations (example, a new distribution or pricing system, a new promotion strategy) do not necessarily involve the intervention of third parties and non-technological innovations are usually developed in close interaction with the service provider, in a co-production process.

As service innovation demands for a more enlarged approach to innovation, Pinto et al (2016) proposed a new tool for analyzing innovation intermediaries' functions in service industry, which encompasses 12 functions of intermediaries (see Table 1).

Table 1. Innovation intermediaries' functions ( Source: Pinto et al (2016))

\section{Function}

1. Analysis and definition of innovation needs

2. Identification of user needs and major trends

3. Signalization of technological options

4. Conceptualization of new service offerings

5. Conceptualization of new organizational methods

6. Conceptualization of new marketing strategies

7. Identification of potential partners

8. Testing and scaling

9. Selection and training of specialised workforce

10. Protection of innovation assets

11. Accreditation/certification

12. Investment appraisal

This framework considers new and renewed functions of intermediaries, due to its larger understanding of the concept innovation (technological and non-technological).

\subsection{Consultancies}

There is a large and increasing number and forms of intermediaries (Dalziel, 2010; Howells, 2006), what makes difficult to enumerate all of them. Consultancies integrate this group, and are a privileged service industry partner due to their ease of access, flexibility and diversity of services (Tether and Tajar, 2008; Pinto et al, 2016). Tether and Tajar (2008) highlight that service companies are more likely than manufacturers to involve consultants than other specialist knowledge providers, while their links to public science-base are weaker. Sánchez-González (2014) concludes that cooperation with consultancies favors the development of both organizational and marketing innovations in service companies.

Consultancies are part of KIBS - Knowledge-Intensive Business Services, helping other companies to be innovative (Lemus-Aguilar et al, 2015). KIBS industries are private companies or organizations, relying heavily on professional knowledge i.e. knowledge or expertise related to a specific (technical) discipline or (technical) functional domain, and supplying intermediate products and services that are knowledge-based (Den Hertog, 2000). 
KIBS are seen to act as facilitators - when supporting a client in its innovation process, but not creating nor transferring innovation from others; carriers - when transferring existing innovations; sources - when triggering and developing innovations in the client; and also as co-producers of innovation - working closely and interactively with the client, in a two-way learning process (Muller and Doloreux, 2009; Winch and Courtney, 2007; Den Hertog et al, 2010; Miles et al, 1995; Bilderbeek and Den Hertog, 1998). According to Muller and Doloreux (2009), there were changes in how scholars perceive and analyze the knowledge content of KIBS activities since. KIBS are perceived not only as knowledge suppliers but as knowledge co-producers since the appropriation of knowledge by KIBS clients is the result of a re-engineering process performed by KIBS in cooperation with their clients.

Pinto et al. (2017) analyzed the role of consultancies as innovation intermediaries in service industry, through the lens of consultancies. They pointed out that service companies are perceived as somewhat distinct clients when compared with manufacturing clients, namely due to their focus on non-technological innovation and reduced dimension and resources. They also concluded that the brokering role of intermediaries loses importance in service context when the focus is non-technological innovation - when consultancies are working on non-technological innovation, they act as co-creators of innovation, working alongside with its clients.

\section{Methodology}

The research aims to understand how consultancies support service companies' innovations processes based on the perspectives of the service companies. It is adopted a multiple case study design which allows to analyze the phenomenon in its natural context and from the perspective of the participants involved in the phenomenon (Yin, 2003; Gall et al, 1996). Case study research design plays an important role in advancing a field's body of knowledge (Merriam, 2009). According to Eisenhardt (1989), case studies are helpful in providing description as well as in testing theory or generating theory. They are considered of particular importance for theory building in areas where existing theoretical and conceptual frameworks are inadequate (Chetty, 1996). In our investigation, due to the emerging nature of the topic in analysis, the case study design allows to provide a rich understanding of the phenomenon of innovation intermediation in service industry, through the lens of service companies.

Purposive sampling was used to select the cases, in line with Eisenhardt (1989)'s argument that building theory from case studies relies on theoretical, not statistical, sampling. Using professional contacts in industry and academia, different cases were identified based on the the criterium that the topic under study was clearly observable and information-rich with respect to the phenomenon under examination. Four organizations were chosen, with prior and considerable experience in consultancy engagement, belonging to private and public spheres, and operating in different and important service industries, to include a diverse set of organizational contexts (see Table 2). The names of the companies have been withheld due to confidentiality reasons. 
Table 2. Cases overview.

\begin{tabular}{lllr}
\hline Name & Headquarters & Industry & $\begin{array}{r}\text { Number of } \\
\text { workers }\end{array}$ \\
\hline Case 1 & Europe & Insurance & 200 \\
Case 2 & Europe & Public Administration (General activities) & 1,500 \\
Case 3 & Asia & Public Administration (Tourism activities) & 400 \\
Case 4 & Asia & Information and Communication & 1,100 \\
\hline
\end{tabular}

Source: Own formulation

Previously to data collection, researchers had a preliminary briefing with a key informant nominated by each company, to understand companies' models of engagement with consultants. They were informed that normally each company has different projects with consultants, and each project is lead and managed by a specific department or division. Consequently, head of departments or divisions were purposefully selected based on their involvement in the companies' projects with consultancies and due to their broader perspective over company's projects and challenges (see Table 3). Main data sources are interviews with heads of departments or divisions and top management (executive directors and vice-presidents). In Case 1, the director of Corporate Communications \& PR is also one of the executive directors of the company, what allowed a richer testimony. In Case 2, the head of Procurement and Financing Management has a transversal knowledge regarding the usage of consultancies by the other departments, since his department is responsible for the organizations's procurement. In Case 3, it was interviewed the company's former director due to his extensive experience in the industry. The interviewee managed the company for more than two decades and still works in public administration, in tourism industry. Also in Case 3, the testimony of the senior executive focuses on the activities of two departments (department of organizational planning \& development; department of events). In Case 4, the interviews to VPs provided a broader picture of the company engagements with consultants, not restricted to their departments.

The data collection took place between July of 2017 and January of 2018. It was performed 13 interviews, with an average duration of 60 to 90 minutes. Due to time constraints, Case 1 director of human resources requested to present his testimony by writing. It was prepared a questionnaire drawing on the interview guide.

The interview guide was designed taking in account the existing literature on innovation intermediaries and on service innovation. The literature was critical to gain insight to the phenomenon under investigation, and to drive and refine questioning. Due to the exploratory nature of the enquiry, it was built a semi-structured guide, with open-ended questioning, allowing respondents' slack. The guide was oriented around three main blocks: Motivations \& Expectations, Collaboration Process and Results (see Fig.1). 
Table 3. Data collection overview.

\begin{tabular}{|c|c|c|c|}
\hline Company & Industry & Departments & $\begin{array}{l}\text { Collaborators } \\
\text { interviewed }\end{array}$ \\
\hline \multirow[t]{5}{*}{ Case 1} & \multirow[t]{5}{*}{ Insurance } & $\begin{array}{l}\text { Information Technologies - Business } \\
\text { Applications (BA) }\end{array}$ & Head of BA \\
\hline & & $\begin{array}{l}\text { Finance - Accounting \& Treasury } \\
\text { (AT) }\end{array}$ & Head of AT \\
\hline & & Digital & Director \\
\hline & & Corporate Communications \& PR & $\begin{array}{l}\text { Director / Executive } \\
\text { Director }\end{array}$ \\
\hline & & Human Resources & Director \\
\hline \multirow[t]{4}{*}{ Case 2} & \multirow{4}{*}{$\begin{array}{l}\text { Public } \\
\text { Administration } \\
\text { (General } \\
\text { activities) }\end{array}$} & Finance - Public Procurement \& & Head of PP\&FM \\
\hline & & Financing Management (PP\&FM) & \\
\hline & & $\begin{array}{l}\text { Urban Planning \& Development } \\
\text { Promotion }\end{array}$ & Director \\
\hline & & $\begin{array}{l}\text { Municipal Works - Studies \& Projects } \\
\text { (S\&P) }\end{array}$ & Head of S\&P \\
\hline \multirow[t]{3}{*}{ Case 3} & Public & Organizational Planning and & Senior Executive \\
\hline & $\begin{array}{l}\text { Administration } \\
\text { (Tourism }\end{array}$ & Development & \\
\hline & activities) & - & (former) Director \\
\hline \multirow[t]{4}{*}{ Case 4} & \multirow[t]{4}{*}{$\begin{array}{l}\text { Information } \\
\text { and Communi- } \\
\text { cation }\end{array}$} & Strategy \& Business Performance & $\begin{array}{l}\text { VP Strategy \& } \\
\text { Business } \\
\text { Performance }\end{array}$ \\
\hline & & Business Quality Assurance & Director \\
\hline & & Legal \& Regulatory & VP Legal \& \\
\hline & & & $\begin{array}{l}\text { Regulatory / } \\
\text { Executive Director }\end{array}$ \\
\hline
\end{tabular}

Source: Own formulation 

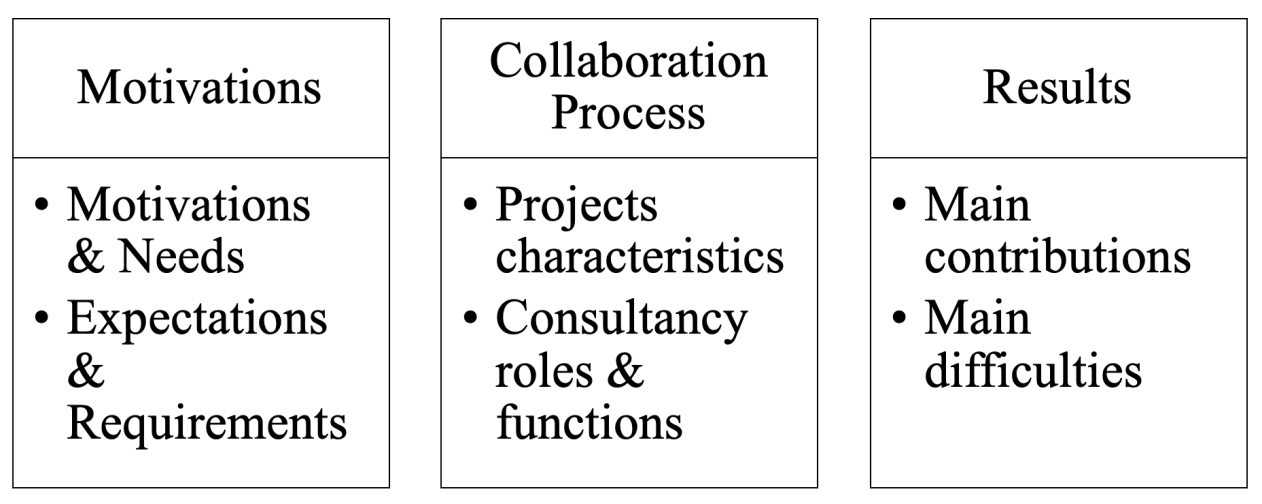

Fig. 1. Components analyzed in the interviews

Interviewees were asked to identify major innovation projects developed with consultancies and, with reference to those, to describe their motivations and requirements when engaging with consultancies; to characterise the collaboration process (projects characteristics such as duration, stages, teams involved from both parties, main roles and functions provided by consultancies), and to evaluate the results (consultancies' contributions and difficulties along the process). All interviews were recorded and transcribed verbatim.

Other sources of evidence were explored such as internal documents provided by companies, information from websites and media (press and social media) as well as direct observation.

Data analysis was performed using qualitative content analysis, which allows the analysis of text within their context of communication, following analytical rules and procedures, without rash quantification (Mayring, 2000). This type of analysis allows triangulation to occur on two levels: by integrating different data sources; by applying a method of data analysis that has not been mainly developed for case study research (Kohlbacher, 2006). The categories and sub-categories were developed deductively from the research questions and literature review and new categories and sub-categories emerged inductively from the data analysis (see Table 4).

The four cases were analyzed separately and then compared, looking for similarities and differences.

\section{Multiple Case Studies: Results}

\subsection{Cases presentation}

\section{Case 1}

The company was founded over 30 years ago, being part of a multinational group, and specialising in insurance and risk consulting. It is one of few brokers that works with Lloyd's of London worldwide, having direct access to the world's largest specialized insurance market. The group has direct presence in European, African and South American markets. 


\section{Key projects with consultancies}

- Internal management platform integrating insurance information from customers and other partners

- Web portal for customers' online management of insurance portfolio

- Introduction of a new ERP system (financial areas)

- Project focused on the creation of a positive corporate culture and sense of belonging

- Training project focused on managing media interlocutors

- Ongoing support (communication issues and events)

- Ongoing support (legislation, human resources matters)

- Training (several areas)

Case 2 The organizations is the municipal council of a county and its mission is to define and execute policies to defend the interests and satisfy the needs of the local population. It aims to promote the development of the municipality in all areas of life, such as health, education, social action and housing, environment and basic sanitation, land use and urban planning, transport and communications, public supply, sport and culture, consumer protection and civil protection.

\section{Key projects with consultancies}

- Economic viability studies (to integrate municipal projects eligible for external funding)

- Urban planning studies (eligible for external funding)

- Technical support (such as the support regarding effective communication, through design, in architectural projects; engineering and legal advice)

- Training (several areas)

Case 2 The organizations is a public entity responsible for implementing, analyzing and assisting in formulating market tourism policies. It promotes local tourism products, playing a significant role in fostering the improvement and diversification of tourism products as well as promoting, coordinating or facilitating a variety of tourism projects and mega events. To fulfil its mission, it has representatives and delegations worldwide that tailor make promotion schemes and activities according to each market's needs. As the supervising entity for the local tourism industry, it ensures the sector's operations are under legal framework by licensing and inspecting the establishments, venues and activities. Additionally, it promotes training opportunities for local sectors through collaboration with training institutes and tourism entities.

\section{Key projects with consultancies}

- Tourism industry development master plan

- Implementation of local tourism events

- Organizational development studies (preparatory studies about the creation of new entities, new models of partnerships) 
- Events' impact studies

- Market studies

Case 4 The company is a leading telecom service provider, offering mobile, fixed telephony, fibre broadband and integrated telecom solutions, in consumer and business markets. In activity for more than 35 years, it employs around 1,100 staff. It has introduced in its local market a number of major service innovations such as the first mobile prepaid service, first multi-number SIM service, first 3G service, first and most extensive online service portal.

\section{Key projects with consultancies}

- Scenarios' analysis and strategy definition

- Integrated billing system

- Customer satisfaction surveys

- Tender bids preparation

- Training (several areas)

\subsection{Results}

Drawing on a hybrid approach, the research started with predefined categories and sub-categories, intended to help guide analysis, and new categories and sub-categories emerged from the data. Table 4 depicts data's categories and sub-categories and the companies in which they have been observed.

Table 4. Categories and subcategories.

\begin{tabular}{|c|c|c|c|c|c|}
\hline Category & Sub-category & Case 1 & Case 2 & Case 3 & Case 4 \\
\hline \multicolumn{6}{|c|}{ Motivations \& Needs ${ }^{1}$} \\
\hline & Information/advice ${ }^{1}$ & $\mathrm{x}$ & $\mathrm{x}$ & $\mathrm{x}$ & $\mathrm{x}$ \\
\hline & Access $^{1}$ & & & $\mathrm{x}$ & \\
\hline & Funding $^{1}$ & & $\mathrm{x}$ & & \\
\hline & Methodology $^{2}$ & $\mathrm{x}$ & $\mathrm{x}$ & $\mathrm{x}$ & $\mathrm{x}$ \\
\hline & $\begin{array}{l}\text { External voice } \\
\text { (accuracy, credibility) }^{2}\end{array}$ & & $\mathrm{x}$ & $\mathrm{x}$ & $\mathrm{x}$ \\
\hline \multicolumn{6}{|c|}{ Expectations \& Selection Criteria ${ }^{2}$} \\
\hline & Knowledge $^{2}$ & $\mathrm{x}$ & $\mathrm{x}$ & $\mathrm{x}$ & $\mathrm{x}$ \\
\hline & Experience $^{2}$ & $\mathrm{x}$ & $\mathrm{x}$ & $\mathrm{x}$ & $\mathrm{x}$ \\
\hline & Reputation $^{2}$ & & $\mathrm{x}$ & $\mathrm{x}$ & $\mathrm{x}$ \\
\hline & Creativity $^{2}$ & & $\mathrm{x}$ & $\mathrm{x}$ & $\mathrm{x}$ \\
\hline & Diagnostic skills $^{2}$ & $\mathrm{x}$ & $\mathrm{x}$ & $\mathrm{x}$ & $\mathrm{x}$ \\
\hline
\end{tabular}




\begin{tabular}{|c|c|c|c|c|c|}
\hline Category & Sub-category & Case 1 & Case 2 & Case 3 & Case 4 \\
\hline & $\begin{array}{l}\text { Project management } \\
\text { skills }^{2}\end{array}$ & $\mathrm{x}$ & $\mathrm{x}$ & $\mathrm{x}$ & $\mathrm{x}$ \\
\hline & Problem solving skills ${ }^{2}$ & $\mathrm{x}$ & $\mathrm{x}$ & $\mathrm{x}$ & $\mathrm{x}$ \\
\hline \multicolumn{6}{|c|}{ Type of projects ${ }^{2}$} \\
\hline & Strategical $^{2}$ & $\mathrm{x}$ & $\mathrm{x}$ & $\mathrm{x}$ & $\mathrm{x}$ \\
\hline & Operational $^{2}$ & $\mathrm{x}$ & $\mathrm{x}$ & $\mathrm{x}$ & $\mathrm{x}$ \\
\hline \multicolumn{6}{|c|}{ Model of engagement ${ }^{1}$} \\
\hline & Dyadic $^{1}$ & $\mathrm{x}$ & $\mathrm{x}$ & $\mathrm{x}$ & $\mathrm{x}$ \\
\hline & $\begin{array}{l}\text { Triadic or multiple } \\
\text { partners }{ }^{1}\end{array}$ & $\mathrm{x}$ & & $\mathrm{x}$ & $\mathrm{x}$ \\
\hline
\end{tabular}

\begin{tabular}{|c|c|c|c|c|}
\hline $\begin{array}{l}\text { Facilitators of } \\
\text { innovation }^{1}\end{array}$ & & & & \\
\hline Carriers of innovation ${ }^{1}$ & & & & $\mathrm{x}$ \\
\hline Sources of innovation ${ }^{1}$ & & & & \\
\hline $\begin{array}{l}\text { Co-producers of } \\
\text { innovation }^{1}\end{array}$ & $\mathrm{x}$ & $\mathrm{x}$ & $\mathrm{x}$ & $\mathrm{x}$ \\
\hline \multicolumn{5}{|l|}{ Consultancy functions ${ }^{1}$} \\
\hline $\begin{array}{l}\text { Analysis and definition } \\
\text { of innovation needs }{ }^{1}\end{array}$ & $\mathrm{x}$ & $\mathrm{x}$ & $\mathrm{x}$ & $\mathrm{x}$ \\
\hline $\begin{array}{l}\text { Identification of user } \\
\text { needs and major } \\
\text { trends }^{1}\end{array}$ & $\mathrm{x}$ & $\mathrm{x}$ & $\mathrm{x}$ & $\mathrm{x}$ \\
\hline $\begin{array}{l}\text { Signalization of } \\
\text { technological options }{ }^{1}\end{array}$ & $\mathrm{x}$ & & & $\mathrm{x}$ \\
\hline $\begin{array}{l}\text { Conceptualization of } \\
\text { new service offerings }{ }^{1}\end{array}$ & $\mathrm{x}$ & $\mathrm{x}$ & $\mathrm{x}$ & $\mathrm{x}$ \\
\hline $\begin{array}{l}\text { Conceptualization of } \\
\text { new organizational } \\
\text { methods }^{1}\end{array}$ & $\mathrm{x}$ & & $\mathrm{x}$ & $\mathrm{x}$ \\
\hline $\begin{array}{l}\text { Conceptualization of } \\
\text { new marketing } \\
\text { strategies }^{1}\end{array}$ & $\mathrm{x}$ & & $\mathrm{x}$ & $\mathrm{x}$ \\
\hline $\begin{array}{l}\text { Identification of } \\
\text { potential partners } 1\end{array}$ & & & $\mathrm{x}$ & \\
\hline Testing and scaling ${ }^{1}$ & $\mathrm{x}$ & & & $\mathrm{x}$ \\
\hline
\end{tabular}




\begin{tabular}{|c|c|c|c|c|c|}
\hline Category & Sub-category & Case 1 & Case 2 & Case 3 & Case 4 \\
\hline & $\begin{array}{l}\text { Selection and training } \\
\text { of specialised } \\
\text { workforce }^{1}\end{array}$ & $\mathrm{x}$ & $\mathrm{x}$ & & $\mathrm{x}$ \\
\hline & $\begin{array}{l}\text { Protection of } \\
\text { innovation assets } 1\end{array}$ & $\mathrm{x}$ & & & \\
\hline & \multicolumn{5}{|c|}{ Accreditation/certification ${ }^{1}$} \\
\hline & Investment appraisal $^{1}$ & & $\mathrm{x}$ & & \\
\hline & $\begin{array}{l}\text { Evaluation of } \\
\text { innovation outcomes }\end{array}$ & & & $\mathrm{x}$ & $\mathrm{x}$ \\
\hline \multicolumn{6}{|l|}{ Results $^{2}$} \\
\hline & $\begin{array}{l}\text { Main contributions } \\
\text { (innovation } \\
\text { preparation) }{ }^{2}\end{array}$ & $\mathrm{x}$ & $\mathrm{x}$ & $\mathrm{x}$ & $\mathrm{x}$ \\
\hline & $\begin{array}{l}\text { Main outputs } \\
\text { (improved solutions; } \\
\text { some radical } \\
\text { innovations) }\end{array}$ & $\mathrm{x}$ & $\mathrm{x}$ & $\mathrm{x}$ & $\mathrm{x}$ \\
\hline & $\begin{array}{l}\text { Deficit areas (market } \\
\text { and industry } \\
\text { knowledge, } \\
\text { interactivity) }{ }^{2}\end{array}$ & $\mathrm{x}$ & & $\mathrm{x}$ & $\mathrm{x}$ \\
\hline & $\begin{array}{l}\text { Key critical factor } \\
\text { (deliverables) }^{2}\end{array}$ & $\mathrm{x}$ & $\mathrm{x}$ & & $\mathrm{x}$ \\
\hline
\end{tabular}

${ }^{1}$ Pre-defined categories and subcategories ${ }^{2}$ New categories

Source: Own formulation.

We now discuss each one in more detail.

\section{Motivations \& Needs}

All companies reported engaging consultants because they needed external specialised knowledge or advice, as illustrated in the following quotes:

"This was a major step. We did not have at the time, and we still not have, expertise regarding ERP, so we had to engage consultancies to help us developing our own system." (Case 1- Head of $A \& T$ )

"We need to outsource consultancies to do some technical tasks when we do not have the right competence within the company (...) Technological issues ae gaining more relevance in innovation... and an insurance broker is not a start-up, which develops new technologies." (Case 1 Digital Director) 
"I was given the challenge of developing the local tourism industry, particularly through event creation, and I felt the need to engage consultancies, as specialized entities that provided us advice (...) The more unique the event is, the higher is the need for qualified staff. And we were not ready... we were aware that if we would have wanted to innovate, we needed specialised advice." (Case 3 - (former) Director)

Additionally, the access to other players was evaluated as important by Case 3 when implementing new types of events:

"Consultancies supported us in the organizations of new events and helped us to get in touch with everyone that mattered. It was a lot of work and we were so small... The value of the consultancy to the development of such a project is enormous, because it allows saving time and money and it is very effective" (Case 3 - (former) Director)

"When organizing a specific type of event (...) the consultancy he ensures all contacts with external partners from other countries (...)" Case 3 - Senior Executive

Case 2 Head of S\&P rejected partially that point of view:

"Consultancies provide us advice which can open new horizons to us and indicate shortcuts. But they usually do not establish bridges between us and other partners. That can happen few times, by instance, when the consultancy has is very well-recognised in the market in which it operates and, as natural process, the contacts are facilitated."

Also, Case 4 reported that they did not engage consultancies to get access to other players, even though consultancies can act as important bridges in technological projects, when implementing of a new technology developed by a technological supplier.

Consultancies' support was found of major importance by Case 2, due to their role in preparing organizational applications for external funding.

Furthermore, service organizations reported that their motivations have changed in some way along the life cycle of the relationship and that, nowadays, go beyond information and advice, focusing on methodology:

"I think that in initial stages we were very much about extracting information and understanding from the consultancy. (...) We initially looked for answers: what should we do. But then you wanted to get to plans and implementation and the questions were: how can we do this? how can we avoid this? Definitely, nowadays we look for methodology. And there is a thin line: consultants will guide you but they will not give you the tool box" (Case 4 - VP of Strategy and Business Performance)

"We have learnt a lot from them and based on their survey skills, and on how they ask those questions, we built our own. We learn from them on how they do the data analysis, on how they collect the data (...) and now we are doing more than them (...) because they don't have our IT data, they don't have our network data, so they cannot do more" (Case 4 - Director of Business Quality Assurance)

"Often we have the feeling that we are doing all the work. What the consultancy does is to give some structure to our work, creating some focus, providing methodology" (Case 4 - VP Legal 8 Regulatory)

\section{ISSN 2183-0606}


"More important than bringing other experiences, consultancies bring methodology. Many times, what is missing in the company is the methodology to manage different topics. And often methodologies can help to share some vision at the executive level, a way to manage doubts, problems, opportunities, risks, ... Often what is lacking is methodology and the consultant can bring methodology to greater effectiveness." Case 1 - Digital Director

"They have given us guidance, recommendations, and inputs about which information we should collect, and how to adjust our documents to be well succeeded in our application to external funding" (Case 2 - Director of Urban Planning)

Companies also reported other motivations related with the need to have an external independent voice over companies' activities. This external voice provides assurance in decision making, contributing to service quality, and, simultaneously, inspires (market) trust. Such view is illustrated in the following quotes:

"(...) you have to be a third party to appreciate things. It's like external audits. I have to have the comfort of an independent voice on a certain matter" (Case 4 - VP Legal and Regulatory).

"It is such a big company, and we need a third-party voice. If we just put out our own results, nobody will trust them (...) But, if it is coming out from a third party, that is different" (Case 4 - Director of Business Quality Assurance)

"it is important to have international experts to support us, they provide credibility" (Case 3 Senior Executive)

\section{Expectations \& Selection Criteria}

All service companies highlighted that their expectations when engaging consultancies were focused on the service provider know-how. The provider knowledge is perceived from different perspectives: technical knowledge but also industry and market knowledge. Furthermore, companies looked up for consultancies well-known worldwide, with an international dimension, that supply information they could trust and gave confidence to the market. The following quotes illustrate these expectations:

"It is important that they know about and industry, and in fact they have that knowledge, but the biggest input they give us is their technical knowledge, their specific expertise" (Case 1 - Executive Director)

"They gave us the report of the knowledge and experiences that they acquire about other places and that they consider useful to us. It was a mixture, on the one hand an attempt to lead us, not let us get off the rails, but, at the same time, to add information and knowledge to the enrichment of the proposal" (Case 2 - Director of Urban Planning)

"The work we do with consultancies is a very technical and specific work, which we cannot do internally since we are not technicians in this area (...) We selected a company with international experience, even though they were not profoundly involved in the tourism industry and they did not know well our market (...) but here we do not have international consultancies, large consultancies" (Case 3 - Senior Executive) 
"Our market representatives worked as consultancies and they were selected due to their industry knowledge, social networks and reputation. They were respected in the markets hey operated" (Case 3 - (former)Director)

Additionally, service companies remarked that consultancies should be sources of new ideas and insights and should combine strong diagnostic, project management and problem-solving skills. The following comments highlight this:

"It helps us to make diagnoses and confirm and identifies new approaches, new directions, new ideas. It identifies opportunities, and brings a different perspective, external, bringing to the arena less usual doubts. We are always working together within the company, we have a chip, a software to imagine, and it often makes sense to work with an outside consultant who poses new, and sometimes interesting, doubts, from a different perspective" (Case 1 - Digital Director)

"They were actually adding some value, they asked us why we would not do it in a certain way; they were asking us some questions to clarify our line of thinking, and those enquiries led us to question some of our options. (Case 2 - Director of Urban Planning)

"We have to look at innovation from different angles. Innovation could be doing the same thing but differently. I do think that is one of the areas where consultancies are. They are actually a very good source of rethinking things. Tendency on the operational side is for repetitiveness, process. It is always worthwhile to sit back and listen to other people. But it may be not how you will do it but it may spark creative thought on yourself." (Case 4 - VP of Strategy and Business Performance)

"The consultancy does not tell us what we already know. What it will do is to assemble the organizational knowledge that we already have and then apply it to a particular project" (Case 4 - VP Legal $\&$ Regulatory)

\section{Type of projects}

According to the testimonies, the collaboration processes between the consultancy and the service company can be typified in strategical projects and tactical projects. Strategical projects are long-term projects, related with the exploration of new opportunities, new ideas, mostly focused on definition of strategies and actions, and that impact significantly organizations's activities; tactical projects are short term-projects, mainly related with the implementation of specific actions or events, aiming to cope with companies' lack of resources and expertise, and where deliverables are clearly identified a priori. The following comments convey this idea:

"The company had to present a comprehensive report with the analysis of the current situation as well as the definition of strategies, action plans on the short, medium and long term" (Case 3 - Senior Executive)

"The consultancy was focused both on strategy and project implementation, probably 50/50. At the beginning (consultancies work) was mostly about operations and network building. But, the political situation obviously changed (...) we used to operate on a concession basis and there was always the possibility (relatively small) that your operations would cease due to government review, and that had to be part of the planning. There was a greater amount of scenario planning 
in all bases because we were dealing with a license " (Case 4 - VP of Strategy and Business Performance)

"Several consultancies advised us on how to create and manage specific tourism events. When we thought that it was interesting to create a new type of festival (...) we invited the consultancy that was responsible for the implementation of the best world-festival of that type, to come and help us" (Case 3 - (former)Director)

"We need consultancies to outsource some technical tasks when we do not have the right competence within the company. For example, regarding ESO (Engine Search Optimization) marketing, to do the optimization of keywords and development of some landing pages" (Case 1 - Digital Director)

"In my division, there is not much consulting as a definition of a strategy because the inputs we receive (from consultancies) are already very concrete, focused on an object (...) but while I was working in planning department, I found that much of this consulting took place "previously" and was not about an object, but on a perspective of evolution of the city, a prospect of development that is intended." (Case 2 - Head of SEP)

The importance of consultancies in the implementation of strategical projects in technological areas was highlighted by some of the companies:

"At a given time point, due to our size and geographical presence, we decided it was time to have our own software to manage our clients' portfolio that met our needs and was house branded. We started a project with a foreign consultant to create an exclusive management platform which integrates all insurance information from our customers, enabling efficient and effective management processes. (...) we also had a similar technological project, we wanted to create a web portal for online management and consultation of all insurance exclusive to our customers." (Case 1 - Head of BA)

"This is a big project and it lasts for a few years already. We are replacing all our four billing systems (...) putting everything into one billing system" (Case 4 - Director of Business Quality Assurance)

"(It) will benefit us with significant cost efficiencies, even more important is that it will enable us to deliver a greatly enhanced customer experience, giving our subscribers greater choice and control through accelerated introduction of innovative services and applications, cross-product synergies, unified billing for personalized plans and creative bundling (...)" (Case 4 - Press release about the new billing system)

\section{Model of engagement}

According to the service companies, mostly of the collaboration projects developed with the consultancies were dyadic, involving direct interaction between the company and the consultancy. Often projects involved not only the department that engaged the consultancy but also other company's departments, especially in the case of strategical projects. In some projects, consultancies serve as an interface between the company and other players (clients, suppliers, associations, public institutions, private companies, public, ...), collecting information considered relevant to those projects. 
Case 4 emphasized a collaboration project that involved the company (the client), the consultancy as a middleman, and a third-party (the technology supplier):

"The consultancy is responsible for working in-between the product provider and our company and do all sorts of coordinating work and project work for us (...) They are working as a consultancy at the same time because they try to understand our requirements and try to use those systems to cope with our requirements (...) They have to work with the technology provider to get the results for us" (Case 4 - Director of Business Quality Assurance)

Two companies also reported other models of engagement, in which other type of players actively participated, namely other consultancies. These other consultancies where engaged by the service company or by the main consultancy:

"In fact, there were two external entities, in practice, one more oriented to the consultancy and another to the development of the technological solution" (Case 1 - Head of BA)

"We engaged another consultancy, a local small-sized company, with scholars from the academic side. The purpose of this engagement was to give us support along the whole process. It was not possible for us as technicians to do all this extra-work, monitoring and supervising, since we have other daily tasks to perform (...) That second consultancy analyzed the work and reports of the main consultancy, made recommendations, participated in the meetings" (Case 3 - Senior Executive)

Most part of collaboration processes lasted for a long period, typically more than 6 months or even more than one year, and some of the companies pointed out that after the project completion the consultancy continued to provide support, what tended to happen in technological projects. Service companies declare to favor long lasting relationships, which allow the increasing of mutual knowledge and trust, critical elements to ensure the quality of service provisions. Yet, they felt it can result in complacency, jeopardising the ultimate output, innovation:

They have been working for us for quite a long time (...) But, personally I am not satisfied with their performance. I want to get ideas from them as an expert. But I usually do not get that from them (...) They just work on my requirements and tell me if the new system can cope with them or not. And I don't need this answer. The answer I need from them is how they can make it work, how can we adjust our requirements to make it work? And I haven't heard anything like this from them. It is a one-way conversation" (Case 4 - Director of Business Quality Assurance)

\section{Consultancy roles}

All four service companies perceived consultancies mostly as co-partners in innovation, since they worked alongside with the company to develop shared solutions, in a win-win partnership. The following quotes express this perspective:

"There is always a time to learn from someone who is outside. Whether in my case, or in the consultant's own case, these are always bi-directional processes of learning" (Case 2 - Head of $S E S P)$

"This was the first market-oriented development of insurance and mediation in terms of technology. The consultants already had some know-how but not related to this industry. Neither they 
nor other consulting companies had innovated in this type of technology in this market. They innovated while developing the solution but also learned (...) their know-how became greater" (Case 1 - Head of BA)

"The design (of the tourism plan) was done by the consultant but always supervised by this department (..) In fact, we did not have to be the ones giving the ideas but this consulting company that has to do the study and inform us of the options (...) but we were always making corrections, adjusting their contributions, since they did not have enough knowledge" (Case 3 - Senior Executive)

Case 4 highlighted the role of the consultancies as innovation carriers in technological projects:

"The system is bought from a third party, a billing system provider. This company has a standard billing system but if we use that standard system, we might not be able to adapt it. So, the consultancy is in the middle, they have to think how to build that in the standard system, how to develop a system that meets our requirements" (Case 4 - Director of Business Quality Assurance)

\section{Consultancy functions}

All four service companies acknowledge the critical importance of consultancies in the diagnosis and articulation of innovation needs as well as in the analysis of the user needs and market trends.

"The consultancy interviewed various tourism industry companies as well as companies from other industries, other public services, associations as well as the general public to collect the different perspectives (...) It was also done an analyze of the city's urban planning, traffic, local capacity to receive tourists, touristic attractions, quality of the local offerings (...)" (Case 3 Senior Executive)

"To create the new application, it was made a thorough examination of the existing processes and needs. Different departments were involved, and some elements of the departments of operations, quality, management control and finances were 100\% dedicated to this project" (Case 1 - Head of $B A)$

Two of the companies, Case 1 and Case 4, pointed out consultancies' functions in the identification of possible technological trajectories. For both companies the technological innovation has a strategic importance.

In all four cases, companies described the consultancy's support in the innovation's design. Case 2 remarked its support mostly in the definition of new services, such as the design of a new urbanistic plan. The other service companies considered that consultancies also helped them in the definition of organizational and marketing innovations. Case 1 pointed out the contribution of consultancies in redesigning the companies' organizational processes, as a result of the introduction of new management software, and in the conceptualisation of company's new promotion strategies. Case 3 highlighted the role of consultancies in the redesign of its external network, in the reformulation of internal departments (such as the documentation centre) as well as in the definition of new ways of positioning the brand in different target markets. Case 
4 remarked the consultancies' support at various levels - market research level, concept stores design and definition of customer e-channels.

Case 3 also reported the consultancy support in the identification of relevant partners in the implementation of some new events.

Case 1 and Case 4 focused the consultancies' support in testing innovations. In both companies created technological innovations alongside with consultancies and it was mandatory to test the new platforms before launching them.

Most part of service companies mentioned that human resources training is critical to service quality and that consultancies have an extensive contribution at this level. Training is focused on technical areas but also on behavioral areas. Case 1 human resources director pointed out an innovative project developed with a consultancy, aiming to create moments of sharing and experience of corporate values in order to reinforce the culture and individual and collective commitment.

Most part of the companies did not get consultancies' support at innovation protection level. In Case 1, head of BA reported some involvement of the consultancy in the protection of the new management platform. Nevertheless, specialised players in legal and innovation protection areas had to be involved.

Case 3 and Case 4 also reported the consultancies' support concerning the evaluation of innovation outputs. The assessment of the company's performance and innovation outputs by a consultancy is strategic to redesign services or design new services or new strategies (namely in terms of policies of pricing, promotion, people,...). Simultaneously, it provides assurance on company's decision making and gives credibility to the market. This is a new function, which is not included in Pinto e al at (2016) framework. The following comments highlight this idea:

"Sometimes demonstrating the obvious to outsiders in a scientific way is not simple. Many years ago we designed and implemented a tourism event of major importance and it brought us large awareness worldwide. Nevertheless, there were enquiries regarding the event's profitability (...) at that time, I felt we should make a comprehensive and independent assessment of its economic benefits and I engaged an independent company, specialised in impact analyzes. And it was positive, since using scientific methodologies they concluded of the significant impact of this event in our economy." (Case 3 - (former)Director)

"Consultancies are important to our innovation process, helping us to design or redesign services, or our strategies (...) By instance, looking at the results of client's surveys we detect failures which help us to improve certain areas" (Case 4 - VP Legal and Regulatory)

\section{Results}

In general terms, service companies perceived consultancies' engagement as important partners to support the improvement of their innovation processes and outputs. Consultancies support was found rather important to prepare the company for innovation. Consultancies support is perceived as more critical in the identification of opportunities than in the innovation implementation, even though they can act as project managers. The following quotes convey this point of view: 
"Consultancies gave suggestions and recommendations of what could be some new products (...) Some innovations can be implemented, by instance at maritime tourism level (...) But the plan does not specify exactly what. This has to be implemented and defined by private initiative." (Case 3 - Senior Executive)

"The consultant works more at the diagnostic level, identifying opportunities, but less on the creation of innovation. It can help in the creation of innovation but as head of project to organize the development of the response" (Case 1 - Digital Director)

"I think that in the end the creation of innovation has to come from the company. The spark or idea may be originated from the consultant. But it has to be taken on, absolutely owned by the company. If that doesn't happen, you are not past to failure" (Case 4 - VP of Strategy 8 Business Performance)

Consultancies were considered important partners to improve the quality of the companies' service provision, what can sometimes result in the co-development of highly innovative technological solutions:

"The consultancy is always an added value beyond the installed capacity. It is about advice and information that adds value to what we are doing. We are not expecting it to change radically our perceptions but to adjust them slightly" (Case 2 - Head of SEPP)

"We e are incredibly innovative, it is our DNA, we are restless, we are always looking for new and different things (...) Having the right partners we greatly enhance our ability to innovate" (Case 1 - Executive Director)

"It was something really innovative produced in-house (...) until then, there was no other broker in Portugal with its own software. This stirred our pride indoors." (Case 1 - Head of BA)

Constant interaction between the client and the consultancy was perceived as a key factor to boost collaboration results. In this context, the company has to be adequately prepared to manage and get the best of the interactions. This idea is present in the following quotes:

"Our department was responsible for the interaction with the consultancy team, and there was a department member assigned as project manager. (...) We always had to be supportive, altering, adjusting the contributions because they did not know well our reality" (Case 3 - Senior Executive)

"We have to have the ability to dialogue at a certain specialized level with the consultancies; otherwise, they lead and we do not have control and be drifting from our objectives" (Case 3 (former Director)

"I am always looking for something more interactive in the beginning so that I can have a better result at the end. Otherwise they will do it the same way and tell us the same things. For me interaction with consultancies is really important otherwise I don't get anything from them" (Case 4 - Director of Business Quality Assurance)

"It should be a dynamic process of inputs and outputs between us and the consultancy. The information comes in, I analyze it critically and then I react to it, demanding the consultancy feedback. I believe there is such care, at least in my area" (Case 2 - Head of SEBP) 
Additionally, service companies felt that consultancies should know well the specificities of the (clients') industry and of local market, to foster the collaboration results:

"The difficulty of working with consultancies is that sometimes they fail to respond to our needs since they are not aware of our local reality, especially the international consultants (..) They do not understand the local legislation (...) They think they can change things from one day to another but it is not so" (Case 3 - Senior Executive)

"The consultancy should have good knowledge of the client's business: 50\% of consultancies knowledge should be about the client's business knowledge, 50\% about technical knowledge. However, our experience of contact is not quite that. There is a gap in the market. There are many technical savvy people but they know little about client's industry" (Case 1 - Head of AT)

Some companies remarked the importance of defining precisely the boundaries of consultancies' support and setting concrete deliverables associated with consultancies' work. This "tangibilisation of outcomes" is considered important due to the significant costs of the consultancy work. Companies find important to clearly understand for what they are paying for and what will be the ratio benefit/cost. Simultaneously, this clarification is critical to get internal support essential to the project' success, and in this context it is of the utmost importance to explain to staff the expected results of consultancy engagement to get their support. The following comments convey this point of view:

"Nowadays, we are using consultancy less and differently. The days that we were using it as a big bang project, that you took a fleet of consultants, this tends not to happen so much (...) People are wanting to see, literally, deliverables. Ad I think that previously although strategy and reviews and stuff like that were all viewed as useful, in the end there was a feeling that oh, we have done that, but what did we actually achieve?" (Case 4 - VP of Strategy and Business Performance)

"For a long time, we used consultancies as advisors and, simultaneously, as producers of an overall study, and that did not work well. More recently, we are detailing and separating their tasks from ours. We are responsible for the study execution, counting on their input; their task is to provide us guidance, advice, and specific information. This new model works fine." (Case 2 - Director of Urban Planning)

"It is truly important to set the project's aims and expected results (what should be the deliverables)" (Case 1 - Director of Human Resources)

\section{Discussion and conclusions}

\subsection{Discussion}

Service companies perceived consultancies as important innovation partners. Due to their smallsized dimension and lack of qualified human resources, they look for the consultancies' support. These service companies engaged a wide variety of consultancies in areas such as strategy, technology, marketing, economy, internationalization, organizational and human resources, engineering, and law. They reported a large diversity of collaboration projects with consultancies. However, 
not all collaboration projects targeted innovations, i.e. only part of them aimed to create or improve products or processes or to design new marketing or organizational strategies. Our analysis examined specifically the innovation projects developed in cooperation with consultancies.

It seems rather important to separate the consulting work from services provided by consultancies. The companies interviewed shared consulting experiences provided by consultancies but also by other players, namely the university and suppliers. Consulting work is mostly associated with guidance and advice, and this role can and is developed by other players besides consultancies. Nevertheless, service companies pointed out that consultancies are important innovation partners, due to the quality of outputs and prompt response.

According to the testimonies, the company's industry seems to affect the nature of projects developed with consultancies. Companies belonging to insurance and telecommunications industries reported the consultancy engagement to be of the utmost importance in highly innovative technological projects, usually related with information and communication technologies. These projects were considered strategical for the company's competitiveness. This finding is aligned with previous research, that highlights that service industry includes a wide diversity of activities with different approaches to innovation, and there is not a "manufacturing mode" and a separate "service mode" of innovation (Tether, 2005).

Service companies highlighted as main motives to engage consultancies the need for specialized information and advice. Companies look for providers that congregate technical, industry and market knowledge. The access to other players is not considered a key motivation to collaborate with consultancies, unless when a new specific type event is being implemented. In this situation, due to previous experiences and participation in relevant networks, consultancies are an important partner. Furthermore, consultancies are not perceived as relevant actors in innovation funding; however, they can provide support in the completion of the service company's funding application. These findings are consistent with Pinto et al. (2017) study, which points out that consultancies consider that their important contributions are information and advice.

A key finding is that motivations for consultancy engagement change along the relationship life cycle. In later stages of the relationship, a critical motivation for consultancy's engagement by service companies is related with search for methodology. A consulting methodology provides a frame of reference, structure and a prescribed set of activities and tasks that will be undertaken in a particular and logical order. This type of motivation could be explained by the peculiar nature of services. Service companies' provision is characterised by its intangibility and variability, and service companies rely on softer strengths at innovation, such as staff's skills and capabilities. In this setting, process management is critical for companies. In this sense, consultancies are a valuable ally, which can help them help to organize their projects into structured, streamlined processes. Additionally, companies' motives to engage consultancies are related with the need for an external voice. Service intangibility underlines the significance of physical cues in service promotion. Therefore, the reputation of the service provider is considered critical to ensure market trustworthiness and companies look for high-reputable providers, namely with international dimension.

The relationships established between service companies and consultancies are usually one-toone, not involving third parties. The consultancy is not envisaged as a broker, that facilitates 
the company's access to third parties and external technologies, but mainly as a co-producer of knowledge alongside with the company. This finding partially supports Pinto et al. (2017) conclusions, which stress that consultancies, when involved in the development of non-technological innovations in service industry, consider that they are more than facilitators of innovation, acting as co-producers of innovations. Yet, in the case of technological innovations, Pinto et al. (2017) concluded that consultancies envisage themselves as innovation facilitators.

Service companies reported that consultancies main functions are mostly related with diagnosis and market opportunities detection, and, simultaneously, they help to define and conceptualise innovations. This finding is also aligned with Pinto et al. (2017) findings, which highlight the importance of consultancies in the diagnostic and conceptualization of non-technological innovation. The importance of consultancies in the areas of training is also highlighted, what is in line with Pinto et al. (2017) findings.

Consultancies provide extensive training to the company's staff, to increase their skills in technical and non-technical subjects. The formal evaluation of innovation outcomes by consultancies is also found important to trigger new innovations. This a new function of innovation intermediaries in service industry which was not covered by Pinto et al (2017), even though it was considered in Howell's (2006) framework. Service companies do not rely on consultancies to protect their innovations, since in this area they engage other specialized players. This finding also supports Pinto et al. (2017) conclusions.

Projects established with consultancies can be of strategical or more operational nature. Service companies pointed out the strategic role of consultancies in preparing the company for innovation. As an external expert, they take a broader perspective and look at the big picture, helping to spot new opportunities, which many times are not obvious to the company. And, even though companies consider that the innovation implementation should be managed directly by the them, consultancies are perceived as a valuable partner in the operationalisation of some projects, when the company doesn't have the necessary resources to do it efficiently. In this situation, consultancies are perceived as important partners at project management level, due to their past experiences, valuable expertise and extensive network.

When evaluating consultancies' contribution, service companies highighted their support in strengthening the overall quality of the companies' offerings. Additionally, they emphasized the consultancies' role in the co-production of radical innovations, namely in technological projects. Pinto et al. (2017) also pointed out that some consultancies felt that their support was more relevant in technological areas.

Regarding the engagement results, service companies find important to associate the consultancies' work with specific deliverables, due to the intangible nature of the provision. The consultancy work is perceived as a provision that essentially involves guidance and advice, and where clients do not ask for a final product. In this sense, the "tangibilization of outcomes", through its association to a clear deliverable, is considered essential by service companies.

The quality of the engagement is perceived as being a result of significant interactions between the client and the service provider, and service companies find that they should be well equipped to engage. In this setting, even though long-term relationships are favored, they are also envisaged 
as a threat to innovation, since they can result in complacency. Simultaneously, the lack of specific market and industry knowledge by consultancies can endanger the engagement success.

\subsection{Conclusions}

Our investigation contributes to complement and extend existing knowledge on the role and importance of consultancies as key innovation intermediaries in service industry. Drawing on the framework of Pinto and al (2016), which covers the functions of innovation intermediaries in services, and using a multiple case-study approach, it was analyzed the role of consultancies as intermediaries, through the lens of service companies. Furthermore, our findings allow triangulating and complementing findings of the empirical study of Pinto et al (2017), which focused on the consultancies' perspective of their role as intermediaries.

Firstly, we conclude that consultancies support to service industry innovation mostly occurs at strategic level. They are perceived as critical partners in preparing companies to innovate, helping them to spot market opportunities and to define innovation strategies. Their support in the innovation implementation is considered secondary and happens mostly when technological innovation is at stake.

Secondly, new motivations for consultancy engagement are uncovered, namely related with the search for methodology and credibility. Innovation literature emphasizes motivations related with the "tangible outputs", such as information, access to other players and funding. But, in later stages of the relationship, service companies look mostly for consultancies' support in structuring their internal innovation processes or promoting their innovation results.

Thirdly, we point out that consultancies, as key innovation intermediaries in services, act mostly as co-producers of innovation, and their brokering role seems to lose importance. Consultancies support companies in the innovation conceptualization, and are not considered to be bridges to other players in the innovation system. This conclusion is aligned with the first one, since innovation implementation is mostly developed by service companies and, as a result, the contacts with innovation partners are established directly by the companies.

A new function of innovation intermediaries is suggested, related with the evaluation of innovation outcomes. This function was not highlighted in those two studies (Pinto et al, 2016, 2017), even though it was included in the framework proposed by Howells (2006). Consultancies help to conceptualize innovations and as well as to evaluate innovations outputs. This finding is coherent with the other findings, reinforcing our conclusion about the importance of the role of consultancies at strategic level.

Finally, we conclude that there is not a unique service innovation mode and these approach to innovation are certainly not unique to services, and can also be found amongst manufacturers (Castro et al, 2011; Tether, 2005). Consequently, it is important to draw on these findings to ensure the development of a synthesis approach to innovation by pointing to features of innovation that have been largely ignored in studies taking a traditional, technology-focused manufacturing approach to innovation. (Castro et al, 2011; Drejer, 2004) 


\section{Limitations and future research directions}

Our study deepens the understanding of the role of innovation intermediaries, and more specifically the role of consultancies, in service industry innovation, contributing to the synthesis approach of innovation. The research provides the unique perspective of service clients concerning the role and functions of consultancies in service innovation. This is an emergent area of study and our analysis needs to be triangulated and complemented with further studies.

We developed a qualitative study, that does not allow generalization of findings. It may be interesting to validate our findings empirically, developing an adequate scale for questionnairebased survey.

Our analysis focuses on four service organizations belonging to different sub-sectors of services industry. Due to the diversity of the services industry, it is extremely important to extend the analysis to other sub-sectors. Furthermore, it is essential to cover other geographical markets, since innovation systems are country-specific.

A big challenge remains in the horizon that is creating a unique framework to analyze innovation intermediaries' functions, which can encompass innovation in service and in manufacturing industries.

This study provides insights into how consultancies and services companies can maximize the outputs of their engagement. On one side, and through the lens of the demand, consultancies can understand the key motivations of service companies to engage with consultancies as well as their expectations. They can learn more about possible models of engagement, consultancies' functions that are perceived as strategic, as well as critical success factors. This insights will allow consultancies to strenghten and improve their offerings. On the other side, service companies can learn from peer experiences, to have a deeper understanding of consultancies' contributions to their innovation processes, namely to non-technological innovation. Tipically, service companies do not have a systematic and comprehensive approach to innovation, and this research offers them an opportunity to enrich their knowledge about the opportunities and challenges of managing innovation in collaboration with third parties and maximize the results of their future experiences.

\section{References}

Battistella, C., De Toni, A. F. \& Pillon, R. (2016). Inter-organizational technology/knowledge transfer: a framework from critical literature review. The Journal Technology Transfer, 41(5), $1195-1234$.

Bessant, J. \& Rush, H. (1995). Building bridges for innovation: the role of consultants in technology transfer. Research Policy, 24 (1), 97-114.

Caiazza, R. \& Volpe T. (2016). Innovation and its diffusion: process, actors and actions. Technology Analysis \&3 Strategic Management, 29(2), 181-189. 
Cantù, C.; Ylimäki, J.; Sirén, C. A. \& Nickell, D. (2015). The role of knowledge intermediaries in co-managed innovations. Journal of Business 83 Industrial Marketing, 30(8), 951-961.

Castro, L. M., Montoro-Sanchez, A. \& Ortiz-De-Urbina-Criado, M. (2011). Innovation in services industries: current and future trends. The Service Industries Journal, 31(1), 7-20.

Chesbrough, H. (2006). Open Innovation: a new paradigm for understanding industrial innovation. Open Innovation: Researching a new paradigm, 400, 0-19.

Chetty, S. (1996), The Case Study Method for Research in Small-and Medium-Sized Firms, International Small Business Journal, 15(1), pp. 73-85.

Chu, K.M. (2013). Motives for participation in Internet innovation intermediary platforms, Information Processing and Management, 49(4), pp. 945-953.

Dalziel, M. (2010). Why do Innovation Intermediaries exist?. Paper presented at the DRUID Summer Conference 2010 on "Opening Up Innovation: Strategy, Organization and Technology" at Imperial College London Business School, June 16 - 18.

Den Hertog, P., Van Der Aa, W., \& Jong, M. W. (2010). Capabilities for managing service innovation: towards a conceptual framework. Journal of Service Management, 21 (4), 490-514.

Den Hertog, P. (2000). Knowledge-intensive business services as co-producers of innovation", International Journal of Innovation Management, Vol. 4, pp. 491-528.

Hertog, P. Den \& R. Bilderbeek (1998). Conceptualising (service) innovation and the knowledge flow between KIBS and their clients, SI4S Topical paper, 11.

Drejer, I. (2004). Identifying innovation in surveys of services: a Schumpeterian perspective. Research Policy, 33(3), 551-562.

Eisenhardt, K. M. (1989). Building Theories from case study research. Academy of Management Review, 14 (4), 532-550.

Gall, M. D., Borg, W. R. \& Gall, J. P. (1996). Educational research: An introduction. Longman Publishing.

Gallouj, F. \& Savona, M. (2009). Innovation in services: a review of the debate and a research agenda. Journal of Evolutionary Economics, 19(2), 149-172.

Gassmann, O., Daiber, M. \& Enkel, E. (2011). The role of intermediaries in cross-industry innovation processes. $R \& D$ Management, 41(5), 457-469.

Howells, J. (2006). Intermediation and the role of intermediaries in innovation. Research Policy, $35(5), 715-728$.

Klerkx, L. And C. Leeuwis (2009). Establishment and embedding of innovation brokers at different innovation system levels: Insights from the Dutch agricultural sector. Technological Forecasting and Social Change, 76(6),849-860.

Kohlbacher, F. (2006). The use of qualitative content analysis in case study research. In Forum Qualitative Sozialforschung/Forum: Qualitative Social Research (Vol. 7, No.1, Art. 21, pp. 1-30). Institut für Qualitative Forschung. 
Lemus-Aguilar, I., Hidalgo, A. \& Caglian, R. (2015). Innovation in consulting firms: What are the foundations?. Paper presented at the International Association for Management of Technology - IAMOT 2015 Conference, Cape Town, June 8-11.

Lin, H., Zeng, S., Liu, H. \&Li, C. (2016). How do intermediaries drive corporate innovation? A moderated mediating examination. Journal of Business Research, 69(11), 4831-4836.|Lin, H., Zeng, S., Liu, H. \&Li, C. (2016). How do intermediaries drive corporate innovation? A moderated mediating examination. Journal of Business Research, 69(11), 4831-4836. Mayring, P. (2000). Qualitative Content Analysis. Forum Qualitative Sozialforschung/Forum: Qualitative Social Research (Vol. 1, No. 2, Art. 20), Available at http://www.qualitative-research.net/fqs [Accessed 17.10.2017].

Merriam, S., B. (2009). Qualitative research: A guide to design and implementation, (2nd ed.). San Francisco, CA: Jossey-Bass Publishers.

Miles, I., Kastrinos, N., Flanagan, K., Bilderbeek, R., Den Hertog, P., Huntik, W. \& Bouman, M. (1995). Users, carriers and sources of innovation. Report to DG13 SPRINT-EIMS, 1-117.

Muller, E. And Doloreux, D., 2009. What we should know about knowledge-intensive business services, Technology in Society, 31(1), 64-72.

Pinto, M., Saur-Amaral, I. \& Brito, C. (2017). "Innovation intermediaries in service industry: the role of consultancies". Journal of Innovation Management, 5(4), 73-101.

Pinto, M., Saur-Amaral, I., Brito, C. (2016). Innovation in services: exploring the role of innovation intermediaries. Revista Portuguesa de Marketing, 18(34), 53-64.

Sánchez-González, G. (2014). Cooperation with external agents and non-technological innovations". In Hervás-Oliver, J.L.; Peris-Ortiz, M. (Eds.): Management Innovation (pp. 139-158), Springer, Cham.

Tether, B.S. (2005). Do services innovate (differently)? Insights from the European innobarometer survey. Industry and Innovation, 12 (2), 153-184.

Tether, B.S. \& Tajar, A. (2008). Beyond industry-university links: sourcing of specialist knowledge for innovation from consultants, private research organizations and the public science base. Research Policy, 37(6-7), 1079-95.

Yin, R. K. (2003). Case study research: Design and methods (3rd ed.). Thousand Oaks, CA: Sage publications.

Winch, G.M. \& R. Courtney (2007). The organization of innovation brokers: An international review. Technology Analysis\& Strategic Management, 19(6), 747-763. 


\section{Biographies}

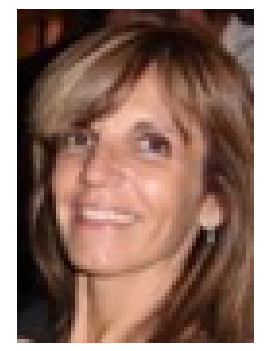

Manuela Pinto. Manuela Pinto holds a degree in Economics, a post-graduation in International Management, a Master of Science in Management (specialization in Marketing and Strategy), and is concluding her $\mathrm{PhD}$ in Management. Manuela was born in Porto, where she lived until 2014. In August of that year, she relocated with her family to Macau SAR. She is a Visiting Lecturer at University of Saint Joseph, in Macau, and at Macau Polytechnic Institute, teaching management, marketing and innovation topics.

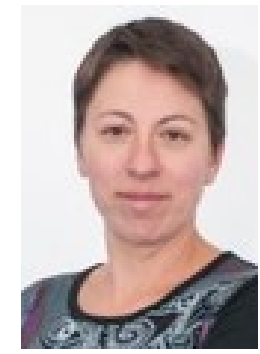

Irina Saur-Amaral. Irina Saur-Amaral has a PhD in Industrial Management (International R\&D in Pharmaceutical Industry), a MSc in Information Management and a BSc in Business Affairs. She has been teaching in higher education since 2006, in areas linked to Management, Marketing, Strategy, Innovation, Business Intelligence and Methodology in Social Sciences, in all levels of higher education and in executive training (postgraduations and in-company). She is currently Coordinator Professor at Universidade de Aveiro - Instituto Superior de Contabilidade e Administração. She founded and managed for 4 years an academic R\&D Unit. She was Director of a Higher Education Institution. She was a consultant for more than 10 years, working closely with Portuguese companies to increase their competitiveness. She has more than 100 publications in journals, conference proceedings and book chapter, and she authored 8 books. She is Expert for European Commission and was the unique Portuguese member of the Advisory Board of EUWIN - European Workplace Innovation Network. Updated profile can be consulted on Linkedin: https://www.linkedin.com/in/irinasauramaral.

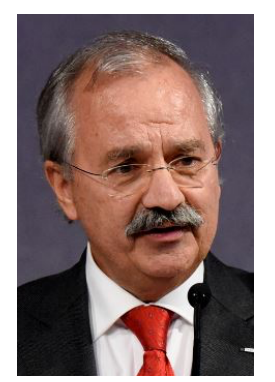

Carlos Brito. Carlos Brito is professor of marketing at the Faculty of Economics and Porto Business School (University of Porto) where he has been responsible for managing and directing business programs. He is vice-president of the Portuguese Management Association, member of several advisory boards and Knight of the Port Wine Brotherhood. For seven years he served the University of Porto as Pro-Rector for innovation and entrepreneurship, board member of UPTEC - The Science and Technology Park of the University of Porto, CEO of NET - Business Innovation Centre and president of the General Council of CEdUP - Club of Entrepreneurship of U.Porto. Carlos Brito has a wide experience in the context of the interface university-industry, having conducted projects and studies for both Portuguese and foreign companies and other organisations. He was awarded 'Personality of the Year 2018' by the Business Angels Portuguese Association and was recognised as one of the sixteen "Portuguese Management Masters", a book published by Jorge Nascimento Rodrigues in 2004.

\section{ISSN 2183-0606}

http://www.open-jim.org

http://creativecommons.org/licenses/by/3.0 